\title{
LAW AND PRACTICE OF THE UNITED STATES IN THE ACQUISITION AND GOVERNMENT OF DEPENDENT TERRITORY.
}

In the following paper I wish to consider two questions : (I) What is the basis in constitutional law for the acquisition and government of dependent territory by the United States? (2) Has the federal government, as a matter of practice, conformed to the law in these two respects?

I. Law: (a) acquisition. There is no clause in the constitution which directly refers to the acquisition of territory by the United States ; the right to acquire territory is neither expressly given nor expressly denied. It has generally been assumed, nevertheless, that the right exists because it is one of the rights inherent in a sovereign state, and the framers of the constitution, therefore, had they intended to deny the power to the government which they created, would have inserted in the constitution a specific statement to that effect. No one but Jefferson apparently, ever thought it necessary to resort to a constitutional amendment for the purpose of legalizing acquisitions of territory, and even he gave up the idea after vainly urging its necessity, during the summer of I803. The theory which the leaders of Jefferson's party put forward to justify the acquisition of Louisiana was that the constitution, though it did not directly give the right to acquire new territory, did so indirectly, through the treaty making power and the war power. Twenty-five years later the supreme court, speaking through Justice Marshall, took exactly the same view, in the case of the American Insurance Co. v. Canter." "The constitution confers absolutely on the government of the Union the powers of making war and of making treaties ;

1 . Pet. 542. 
consequently that government possesses the power of acquiring territory either by conquest or by treaty." This decision has never been reversed. A modification of it was attempted in the case of Dred Scott, but as that portion of the opinion is generally agreed to have been an obiter dictum, it will be better to omit the case of Dred Scott from further consideration, spite of the fact that it contains the most exhaustive discussion of the whole subject of the acquisition and government of territory to be found in the entire range of judicial decisions. ${ }^{1}$ On the other hand the decision of Justice Marshall has been repeatedly confirmed by decisions before and since the time of Dred Scott. It may be confidently asserted therefore, with little fear of contradiction, that the law of the acquisition of territory by the United States is this: The federal government may acquire territory by treaty or by conquest.

(b) Government. The question of the right to govern dependent territory does not. arise, because this right, is granted to the federal government, in terms, by the constitution." "Congress shall have power to dispose of and make all needful rules and regulations respecting the territory or other property belonging to the United States." The question here is not may Congress govern the territories, but how may it govern them.

This on the face of it would seem, perhaps, an easy question to decide. The grant of power to Congress seems to be plenary. Shall we not answer, therefore, that Congress may govern the territory which has been acquired, in any manner it desires, absolutely and without limit? But the question is not so simple. There are in the constitution certain specified things which Congress is not permitted to do : Congress may not pass an ex post facto law, or a bill of attainder, or authorize the trial of a person accused of crime, except by a jury. There are many other things which Con-

1 I9 How. 393.

Constitution, IV, 3 . 
gress is in terms forbidden to do. Taken together, these prohibitions constitute the realm of liberty, within which the sovereign power of the state, speaking through the constitution, frees the individual from all interference by the federal government. Now, the core of the question at issue is this: Does this realm of liberty exist for the individual within the states and territories, or only within the states? Does the constitution follow Congress into the territories, or when Congress steps into the territories, does it divest itself of all restraint upon its power to legislate? Is there any part of our political system in which the constitution is not the law of the land? The constitution itself says, and no one denies, that it was ordained and established for the United States of America. At bottom, therefore, the question we have to decide here is, what is the legal (not the historical or the logical ) meaning of the term United States. If it means merely the states united, Congress may legally pass bills of attainder and $e x$ post facto laws for the territories; if it means the states united and all other territory over which the federal government exercises jurisdiction, Congress may not legally do these things or any of those things which it is specifically forbidden to do by the constitution.

The term United States is not defined in the constitution. It is sometimes used in the sense of the states united, ${ }^{1}$ and sometimes in the broader sense, ${ }^{2}$ but from the constitution itself no decisive answer can be obtained to the question, what does the term United States mean. The only recourse, therefore, is to the supreme court; the interpretation which it puts upon the term must be decisive of its legal meaning. The leading case is that of Loughborough and Blake," decided in 1820 . "The term United States," said Justice Marshall, " is the name given to our great republic which

1 See article in Review of Reviezes for January, 1899 . H. P. Judson.

See Dependencies and Protectorates, Political Science Quarterly, March, 1899.

${ }^{8} 5$ Wheat. 317 . 
is composed of states and territories. The District of Columbia or the territory west of the Missouri, is not less within the United States than Maryland or Pennsylvania." Omitting from consideration the case of Dred Scott for reasons already mentioned, it will be sufficient to refer to the case of Cross $v$. Harrison, in which this definition of the term United States was repeated specifically, ${ }^{2}$ and to Clarke $v$. Brazadone, 'Clinton v. Englebrecht," and ex parte Bollman," in which this definition of the term United States is clearly assumed as the basis of the decision in each case. In view of these decisions it is believed that the term United States has only one meaning in our constitutional law, and that is this: all of the territory under the jurisdiction of the federal government.

If the United States includes all dependent territory, and if the constitution was made for the United States, it is clear that Congress in governing the territories is limited by all of the constitutional immunities which are absolute as against the federal government. But although this is the logical inference from the proposition that the United States includes the territories as well as the states, the courts, in deciding the direct question of the power of Congress in the territories, may not always have drawn this inference. The question now is, therefore, has the court, in its decision of the specific question of the power of Congress in the territories, been consistent with its interpretation of the term United States. It may be stated at once that, with possible exceptions of minor importance, the court has taken the view which its interpretation of the term United States would seem to make necessary. It has always maintained that the constitution extends to the territories ex proprio vigore, and that Congress is, therefore, not absolute there, but that it has plenary legislative powers modified by the positive and

1 I6 How. I64.

2 I Cranch, 2 r2.

${ }_{13}$ Wall. 434 .

4 Cranch, 75 . 
absolute limitations of the constitution. But the court has been chary of deciding the direct question. It has rarely been necessary indeed, because the constitution has invariably been extended to the territories by specific legislation, and in correcting territorial legislation on constitutional grounds, there has consequently been no necessity of touching upon the question as to whether it extends there of its own force. Obviously the latter question can come before the court only when some direct legislative act of Congress is in review. Fortunately such has been the case in a few instances.

One of the earliest and clearest statements of the power of Congress in the territories was made by Marshall in connection with his definition of the term United States: " The District of Columbia or the territory west of the Missouri is not less within the United States than Maryland or Pennsylvania, and it is not less necessary on the principles of our constitution, that uniformity in the impositions of imposts, duties, and excises should be observed in the one than in the other." In the case of Cross and Harrison, " after interpreting the term United States to include the territories, it was stated that, " the right claimed to land foreign goods within the United States at any point outside of a collection district, if allowed, would be a violation of that provision in the constitution which enjoins that all duties, imposts and excises shall be uniform within the United States." But the fullest and most explicit statement of the power of Congress in the territories, is to be found in the case of Murphy $v$. Ramsey, decided in $1884^{3}$ The question at issue was the law of Congress which made polygamy a crime and deprived of the suffrage those citizens of the territories who were guilty of it. In considering the power of Congress to pass such a law for the territories the court said: "The

1 Loughborough $v$. Blake. 5 Wheat. 317 .

$216 \mathrm{How} .164$.

114 U. S. 
people of the United States, as sovereign owners of the national territories, have supreme power over them and their inhabitants. In the exercise of this sovereign dominion they are represented by the Government of the United States, to whom all the powers of government over that subject have been delegated, subject only to such restrictions as are expressed in the constitution, or are necessarily implied in its terms or in the purposes and objects of the power itself. . . . But in ordaining government for the territories, . . . all the discretion which belongs to legislative power is vested in Congress; and that extends, beyond all controversy, to determining by law, from time to time, the form of the local government in a particular territory and the qualifications of those who shall administer it. It rests with Congress to say whether, in a given case, any of the people resident in a territory, shall participate in the election of its officers or the making of its laws; and it may therefore take from them any right of suffrage it may have previously conferred. . . . The right of local self-government, as known to our system . . . belongs, under the constitution, to the states and the people thereof, by whom that constitution was ordained. . . . The personal and civil rights of the inhabitants of the territories are secured to them, as to other citizens, by the principles of constitutional liberty which restrain all the agencies of government, state and national; their political rights are franchises which they hold as privileges in the legislative discretion of the Congress of the United States." No clearer statement has been made in any case, and a different view has never been held, by the supreme court; on the other hand, the principle here laid down was foreshadowed in the earlier cases of the National Bank v. Yankton County, and Reynolds $v$. the United States. ${ }^{2}$

Though clear in the belief that the constitution extends of

1 IOI U. S.

98 V.S.

\section{[409]}


its own force to the territories, the courts have never clearly decided the precise moment at which the constitution begins to operate in newly acquired territory. In Fleming $v$. Page the court took the position that conquered territory does not become a part of the United States until Congress establishes civil government there, and is not subject to the revenue laws of the United States until it has been erected into a collection district. It was asserted that this construction of the revenue laws had been uniformly given by the administrative department of the government. This view, however, seems in conflict with the idea that the constitution extends of itsown force to the territories, for such a construction would practically mean that the constitution does not extend to the territories until Congress extends it there by legislation with reference to the collection of the revenue. It is also in conflict with a later decision in the case of Cross $v$. Harrison, ${ }^{2}$ in which California was decided to have been a part of the United States from the moment the treaty of annexation was signed; and the collector, appointed under military government, was supported in collecting the duties of the act of 1846 as soon as he had news of the treaty, which was some time before civil government was established or the territory erected into a collection district.

In view of these decisions, the constitutional law of the United States, for the government of dependent territory, may be stated as follows: The term United States, includes states and territories. The constitution was made for the whole United States and extends of its own force over all newly acquired territory, at least as soon as civil government is established there; the constitution gives Congress plenary power of legislation in the territories, subject to the absolute limitations upon its power expressed in the constitution.

2. Practice: (a) acquisition. The practice of the United 
States in acquiring territory may be briefly stated. Aside from the northwest and southwest territory, which was virtually a part of the United States when the present constitution was formed, Louisiana, Florida, Oregon, the Gadsden purchase, and Alaska, were acquired by treaty ; California and the north Mexican states, by conquest in the guise of a treaty ; Texas and Hawaii, by joint resolution of Congress, after an attempt to secure them by treaty had failed. The practice of the United States in acquiring territory has therefore conformed to the constitutional law on the subject in every case, save possibly that of Texas and Hawaii ; for the method by which these territories were acquired, it is believed, there is no basis, strictly speaking, in the constitutional law of the United States.

(b) Government. The question now to be discussed is this: Has Congress, in practice, governed the territories within the limitations which the court decisions lay down as necessarily binding? First, however, it will be well to keep in mind the distinction, which the court drew so clearly in the case of Murphy $v$. Ramsey, between civil rights and political privileges in the territories. That undemocratic governments have been established in the territories does not mean that the privileges guaranteed in the constitution have been denied them. The undemocratic form of first grade territories established by the northwest ordinance, has been frequently referred to by various writers as proving the absolutism of Congress in the territories. This is certainly a misconception. Even those who contend that the constitution extends of its own force to the territories do not maintain that this guarantees the establishment of republican government there. The privileges which individuals enjoy as against the federal government are not political (with one exception, since the civil war); they are in the nature of personal immunities and property rights. It is not contended that the rule for interpreting the powers of Congress in the territories is the same as that for interpreting its powers in 
the states. In the latter case the rule is that all powers not specifically granted to Congress or denied to the states are reserved to the states or to the people; but in the territories Congress has been given general legislative power, and the rule for interpreting its powers (assuming that the constitution extends to the territories of its own force) is, that all powers not specifically denied to Congress are reserved to Congress. The only constitutional rights which the territories possess absolutely are defined in the absolute limitations upon the power of Congress. The right to establish undemocratic governments is not denied to Congress. The question, therefore, is not, has Congress denied to the inhabitants of the territories political privileges, but has it denied them the personal liberties and the property rights guaranteed to every individual against the federal government.

In treating this question it will be convenient to notice (I) the theory of its own power in the territories upon which Congress has acted, and (2) whether Congress has actually denied to the territories rights which, according to judicial interpretation, are secured by the constitution.

It may be stated confidently that the theory upon which Congress has generally, if not invariably, acted is the exact opposite of that which the supreme court has always maintained. Both have believed that the constitution was made for the United States; but the court has defined the United States to mean the states and territories, while Congress has defined the United States to mean the states alone. The former has concluded, therefore, that Congress does not rid itself of constitutional limitations when it steps into the territories; the latter has concluded that it does.

That this has been the theory upon which Congress has acted is clear from the fact that whenever new territory has been acquired, and civil governments established, the constitution and laws of the United States have been extended to it by specific legislative action. The revenue laws of the United States were extended to the northwest territory in [412] 
1794, to the territory acquired from France in $\mathrm{I}_{80}$, tc Florida in 1821 , to Oregon in 1848 , to California in 1849 , and to Alaska in 1868 . Practically every territorial act contains the provision that no law shall be passed by the local government which is contrary to the constitution, and in many instances more or less careful enumerations of personal and property rights are included in these acts as being reserved to the inhabitants, although the same rights are enumerated more fully in the constitution itself. Specific legislation by Congress extending the constitution to the territories, and granting them rights already named in the constitution, clearly shows that Congress believed these rights might have been denied, and that the constitution does not extend to the territories of its own force. The Louisiana debate, and the debate on the admission of Missouri, show this to have been the all but unanimous opinion; it was not until the growing strength of the North in Congress forced the southern Democrats to reconstruct their constitutional law that the opposite view, reflected in the Dred Scott decision, began to prevail; but this influence was only reactionary, and, from the point of view of territorial administration, never produced anything more effective than the nondescript theory of popular sovereignty.

But Congress may have acted upon the theory that the personal and property rights guaranteed in the constitution might legally be denied to the territories without, as a matter of fact, denying them. The question now under consideration is, what has Congress done in the territories which it might not have done had it held the same theory which the supreme court has held? In considering this question it will be convenient to notice: ( 1 ) the powers given by Congress to its agents, the local territorial governments; (2) the direct administrative legislation of Congress.

The first territorial government was created by the northwest ordinance of $1787 .^{1}$ It contained a compact securing

'Poore, "Charters and Constitutions," 429.

[4I3] 
for the northwest territory personal and property rights nearly coextensive with those secured later in the present constitution. It also contained a clause forbidding the territorial government to do anything inconsistent with the articles of confederation or any subsequent alteration of them constitutionally made. It was clearly intended, therefore, that the articles of confederation should operate in the northwest territory so far as the local government was concerned. Now one of the early acts of the first Congress under the new government, in 1789 , was an act adapting the northwest ordinance to the new constitution. Such alterations as were thought necessary or desirable to put the ordinance in the same relation to the constitution that it had sustained to the articles of confederation, were made. The provision just noticed was left unchanged, and it seems reasonable to assume that it was the intention to subject the territorial government to the constitution in precisely the same way it had been subjected to the articles of confederation. In view of this provision and the articles of compact, therefore, it cannot be said that the government established by the northwest ordinance denied at least any important right guaranteed by the constitution against the federal government. With slight modifications the ordinance was re-enacted for the territories of Indiana, ${ }^{1}$ Illinois ${ }^{2}$, and Michigan; ${ }^{3}$ with the exception of the slavery clause, for the original southwest territory $;^{4}$ for Mississippi ${ }^{5}$ and Alabama; ${ }^{6}$ and although an entirely new act was passed for the territory of Wisconsin in $1836,{ }^{7}$ it also contained a clause giving to the inhabitants all of the rights enumerated in the northwest ordinance, and extending the laws of the United States to the territory so far as applicable.

\footnotetext{
1 Poore, "Charters and Constitutions," 1453.

2 Ibid., 435.

Annals of Congress, 1804-05, p. 1659.

4 Ibid., I 789-91, p. 2226.

- Ibid., Fifth Congress, iii, p. 37 I9.

- Ibid., Fourteenth Congress, Second Session, Izra

? Poore, "Charters and Constitutions," 2021.
} 
The first act providing in any way for a government of the Louisiana territory was passed October $30,1803 .{ }^{1}$ It was not entitled an act for the government of Louisiana, but an act authorizing the President to take possession of Louisiana. It was merely temporary in its nature, and designed for the purpose of preserving order until Congress could provide a permanent civil government. It gave absolute freedom of action to the President, and authorized him to use the entire military power of the United States to maintain order. An essentially similar act was passed for Florida, March 3, I821. ${ }^{2}$ These acts have been referred to as evidencing a congressional policy of the extremest absolutism in the territories. But, strictly speaking, they should not be considered as a part of the congressional administration of the territories at all; they are in reality acts by which military government was established in ceded territory. At present the President might establish such temporary governmental authority with or without the authorization of Congress; but that means that the military powers of the President in our constitutional system were then much less clearly worked out than they have since become. For these reasons, therefore, it is believed that a review of the civil administration of the territories by Congress may justifiably omit these two acts from consideration; they represent the means then used to establish military government in ceded territory.

Civil government was first established in Louisiana in 1804. ${ }^{3}$ The new acquisition was divided into the territory of Orleans and the district of Louisiana, the former comprising practically the present State of Louisiana, and the latter everything else. The government established in both regions was undemocratic, but neither was permitted to pass any law inconsistent with the constitution of the United States. The next year a new governmental act was passed

\footnotetext{
${ }^{3}$ Annals of Congress, Fighth Congress, First Session, 1245

2 Ibid., Sixteenth Congress, Second Session, 1809.

${ }^{3}$ Ibid., Eighth Congress, First Session, 1293.
}

[4I5] 
for the territory of Orleans, ${ }^{1}$ and one which erected the district of Louisiana into the territory of Louisiana; ${ }^{2}$ in both of them the same prohibition was placed upon the power of the local government. In I8I2 the territory of Louisana became the territory of Missouri under a new act, ${ }^{3}$ which, besides the same prohibition, contained a rather elaborate enumeration of rights secured to the inhabitants. This territory, like the original northwest territory, was gradually divided into a number of territories as the vast region became more thickly settled; and in all of the subsequent territorial acts within the original Louisiana territory, the same clause was introduced forbidding any law inconsistent with the constitution of the United States. Civil government was first established in Florida in March, 1822." It was based upon the Orleans act of 1804 , but also contained an enumeration of civil rights similar to that in the Missouri act of 1812 . It also contained the provision that all legislation must be consistent with the constitution of the United States. The Oregon act of $1848,{ }^{5}$ and the act for the territory of New Mexico of $1850,{ }^{6}$ contained similar provisions, as did the later acts by which the original Oregon and New Mexican territories were divided. California never had, strictly speaking, a territorial existence; and Alaska, organized under the act of $\mathbf{1} 884$, does not possess a local legislature.

From the above review of the powers of the local governments in the territories, it is clear that Congress has in every case limited these governments by all of the provisions of the constitution; the agents of Congress in the territories have not been permitted to disregard any constitutional limitation. Outside of the local governments, however, Congress has the right, which it has constantly exercised, of legisla-

1 Annals of Congress, Second Session, I674.

2 Ibid., 1684 .

' Ibid., Twelfth Congress, 2310.

1 Ibid., Seventeenth Congress, First Session, 2578.

- Poore, "Charters and Constitutions," I49r.

- Statutes at Large, ix, 446.

TIbid., $\mathrm{x \nabla}, 240$. 
ting directly for the territories; and this direct legislation has no necessary connection with, and in case of conflict always supersedes, the territorial acts or constitutions. It is now necessary to consider some aspects of this direct administrative legislation.

For the purposes of the present paper, only those subjects of legislation are pertinent which refer to the positive prohibitions in the constitution upon the power of Congress. These subjects may all be grouped under two general heads: (I) personal liberties; (2) property rights. Has Congress denied these rights to the territories, as a matter of fact, notwithstanding it has held the theory that it might legally do so ? Those constitutional provisions which I have grouped under personal liberties are of such a nature that legislation with respect to them has necessarily been left for the most part to the local legislatures ; direct legislation by Congress has been very rare. Questions of general search warrant, excessive bail, fines, and punishments, unreasonable delay in trial, the form of indictment and trial, freedom of speech and of assembly, have never arisen in the territories in such a way as to call for direct legislation by Congress; nor, it is believed, has any bill of attainder or ex post facto law been passed by Congress for the territories, nor the privilege of the writ of habeas corpus suspended there within the meaning of the constitution as interpreted by the courts. Only one of the personal liberties has been the subject of direct legislation by Congress-that relating to religious freedom. Polygamy is claimed to be an integral part of the Mormon religion, but Congress has passed several laws making polygamy a crime in the territories, and visiting with severe penalties those found guilty of practicing it. But the court, while it stated that Congress might not violate the first amendment in the territories, held that marriage was a civil relation and not an attribute of religion in the meaning of the constitution, and that, consequently, the power of Congress over polygamy was coextensive with its power to define and 
punish crime. The definition of crime, like that of property, is, outside of the states, determined by Congress, and the constitutional limitations referring to religion and to crime do not, therefore, in any way abridge the power of Congress to make polygamy a crime in the territories, and punish it accordingly. It is not believed that Congress has by any direct legislation denied to the inhabitants of the territories any of the personal liberties guaranteed in the constitution.

The property rights guaranteed in the constitution lend themselves more readily to direct congressional legislation than do the personal liberties. What is property ? Property, in our political system, is determined by the common law, modified by legislation: within the states the modification can be made only by the state legislatures; outside of the states, only by Congress. Property in the territories, therefore, is anything (with one exception) which Congress makes property. The constitutional limitations upon Congress with respect to property are, that no one may be deprived of property without due process of law, nor shall private property be taken for public purposes without just compensation, nor duties, imposts and excises be levied, except they be uniform throughout the United States. Has Congress violated any of these provisions in the territories? The only important direct legislation by Congress, touching the subject, has been with reference to the revenue and slavery.

Until 1854 Congress pursued a consistent policy with reference to slavery in the territories. It always permitted it in the southern, and prohibited it in the northern territories; east of the Mississippi the line of division was the Ohio River, west of the Mississippi, the arbitrary line of $36^{\circ} 30^{\prime}$. If slaves were property, the right of individuals in the territories in such property was abridged without due process of law. But the acts of Congress prohibiting slavery in the northern territories, may be interpreted as acts by which Congress defined property there anew, in so far as to exclude human beings: they may be considered as acts about a cer[418] 
tain kind of property, or as acts which removed certain things from the category of property entirely. Practically they had the latter effect, and, looked at in this light, the constitutional limitations with respect to property rights can have no reference to this legislation at all.

As already indicated the all but uniform policy of Congress has been to make the revenue laws uniform for states and territories. The first tariff and internal revenue duties levied under the present constitution, were not levied or collected in the northwest and southwest territories until 1794 . The reason was probably the practical one, that the revenue which might have been collected there, would scarcely more than have paid the cost of its collection. But by the act of June 5, 1794, ${ }^{1}$ the President was authorized to provide for the collection of the internal revenue duties in the territories, by the erection of districts and the appointment of collectors. This was done; and one year later the attorney-general held that the act had the effect of extending all of the revenue laws, present and future, so far as applicable, to the territories. Technically, he said, all revenue laws had extended there from the first, but until collectors were appointed they could not be enforced there; officers once appointed, they became the legitimate agents for the collection of duties arising under all future acts of a general nature. ${ }^{2}$ These suggestions were followed by the treasury department from that date. In like manner, on February 24, I804, Congress, by a special act, extended the revenue laws of the United States, present and future, to the territory ceded by France, and prohibited any discrimination between the territory and other parts of the United States. ${ }^{3}$ The revenue laws of the United States were similarly extended to Florida even before a civil government was established there." The same policy

1 Annals of Congress, $1793-95$, p. 1457 .

- Bradford's reply to St Clair, June 19, 1795. St. Clair Papers, ii, 377.

Annals of Congress, Eighth Congress, First Session, I253.

4 Ibid., Sixteenth Congress, Second Session, p. 1809 .

[419] 
was pursued with reference to Oregon ${ }^{1}$ (which, as organized under the act of 1848 , included all of the territory west of the Louisiana purchase and north of the Mexican acquisition), with reference to California, ${ }^{2}$ and also with reference to New Mexico which originally embraced what remained of the Mexican acquisition. ${ }^{3}$ It is thus seen to have been the almost uniform policy of Congress to subject the territories to precisely the same imposts, duties, and excises, as the other parts of the United States. The only exception occurred in the earliest years of the republic; and it is well to note that in this one case the lack of uniformity had the effect, so far as it had any effect at all, not of denying any right to the inhabitants of the territories, but of granting them a privilege. In no case it is believed has any one of the territories been taxed at a different rate than the rest of the Union.

In summing up the subject it may be said concisely: (I) Congress may acquire territory by treaty or conquest, and has so acquired it in every instance save that of Texas and Hawaii; (2) Congress has all legislative power in the territories which is not specifically denied to it by the constitution, and, though always assuming that it was not limited by the constitution in any respect in the territories, has not, as a matter of practice, directly or indirectly overstepped those limitations.

CARI Becker.

State College, Pa., June, rgoo.

1 Poore, "Charters and Constitutions," 1489, 1491.

Statutes at Large, ix, 400.

Ibid., ix, 446 . 